\title{
Abdourahman A. Waberi, Balbala
}

\section{Ilaria Vitali}

\section{(2) OpenEdition}

\section{Journals}

\section{Edizione digitale}

URL: http://journals.openedition.org/studifrancesi/36818

DOI: 10.4000/studifrancesi.36818

ISSN: 2427-5856

\section{Editore}

Rosenberg \& Sellier

\section{Edizione cartacea}

Data di pubblicazione: 1 juillet 2005

Paginazione: 208

ISSN: 0039-2944

\section{Notizia bibliografica digitale}

Ilaria Vitali, «Abdourahman A. Waberi, Balbala», Studi Francesi [Online], 145 (XLIX | I) | 2005, online dal 30 novembre 2015, consultato il 20 avril 2021. URL: http://journals.openedition.org/studifrancesi/ 36818 ; DOI: https://doi.org/10.4000/studifrancesi.36818

\section{Questo documento è stato generato automaticamente il 20 avril 2021.}

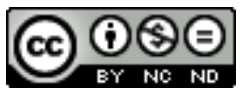

Studi Francesi è distribuita con Licenza Creative Commons Attribuzione - Non commerciale - Non opere derivate 4.0 Internazionale. 


\section{Abdourahman A. Waberi, Balbala}

Ilaria Vitali 


\section{NOTIZIA}

ABDOURAHMAN A. WABERI, Balbala, traduzione e introduzione di M.-J. HOYET, Roma, Edizioni Lavoro, 2003, pp. 125.

1 Il romanzo di Waberi si apre tra le soffocanti mura di una prigione di Balbala, bidonville a sud dell'omonima capitale del Gibuti, da cui il narratore si lancia in una rivisitazione critica del passato del suo paese e delle sorti dell'intero continente africano. Dopo essere stato maratoneta d'eccezione e gloria nazionale, Waïs, narratore e personaggio principale, viene accusato di sedizione e cospirazione contro "l'unità nazionale" e si ritrova rinchiuso in carcere insieme alla sorella e due amici. Di fronte ad un futuro incerto, si rifugia tra le pieghe nascoste del passato e del presente: nella riflessione del protagonista, "i soli delle indipendenze" non costituiscono il lieto fine dell'oscuro periodo coloniale, ma solo l'inizio di un nuovo regime feudale dominato da una dittatura feroce. Costantemente in bilico tra romanzo e novella, la narrazione si avvale di numerosi monologhi interiori, citazioni colte e ritornelli popolari, che dettano il ritmo del racconto, tra rievocazione del passato, osservazione critica del presente e vacillanti slanci in avanti, verso un futuro incerto.

2 A cura di Marie-José Hoyet, la traduzione italiana del romanzo è introdotta da un brillante saggio che illumina la complessa struttura narrativa dell'opera (divisa in quattro parti, con quattro diversi narratori), sottolineando l'originale stile dell'autore, nonché la delicata situazione storico-politica del suo paese, che vive sotto la costante censura di un regime fortemente autoritario. Più che "rendere conto" della delicata situazione postcoloniale, l'autore preferisce "rendere racconto", come lui stesso asserisce, appropriandosi delle parole dello scrittore congolese Tchicaya U Tam'si. Partendo dall'esperienza di un piccolo stato del Corno d'Africa come il Gibuti, la narrazione si apre su uno spazio aperto, quello di un intero continente, e acquisisce così un respiro universale. 